\title{
Relationship between Efavirenz plasma concentrations and CYP2B6 Polymorphism in HIV/TB co-infected Africans taking rifampicin in the treatment Antituberculosis at Abidjan.
}

Ayoman DJADJI', Yapo T. ABA5 N'Douba A. C.KASSI4 Antonio d'AVOLIO², Rodolphe GARRAFFO3; Fréderic ELLO'4, Gisèle SYRANSIKOUAKOU', Lavrut THIBAUT ${ }^{2}$, Giovani DI PERRI ${ }^{2}$ and Emmanuel BISSAGNÉNÉ ${ }^{4}$

${ }^{1}$ Department of Pharmacology / Faculty of Science Pharmaceutical and Biological and Treichville's University Hospital

${ }^{1}$ Department of Pharmacology / Faculty of Science Pharmaceutical and Biological

${ }^{2}$ Laboratory of Clinical Pharmacology and Pharmacogenetics, Department of Infectious Diseases, University of Torino, Amedeo di Savoia Hospital, Corso Svizzera 164, 10149 Turin, Italy

${ }^{2}$ Department of Infectious Diseases, University of Torino, Amedeo di Savoia Hospital, Corso Svizzera 164, 10149 Turin, Italy

${ }^{3}$ Laboratory of Clinical Pharmacology and Medical Toxicology Pasteur's Hospital, Nice, France

${ }^{3}$ Laboratory of Clinical Pharmacology and Medical Toxicology Pasteur's Hospital, Nice, France

${ }^{4}$ Department of Infectious Diseases and Tropical, CHU Treichville's Hospital BPV 03 Abidjan, Côte d'Ivoire

${ }^{4}$ Department of Infectious Diseases and Tropical, Treichville's Hospital BPV 03 Abidjan, Côte d'Ivoire

${ }^{5}$ Department of Infectious Diseases and Tropical, Bouaké's University Hospital , Côte d'Ivoire

\section{Abstract}

Aim: To investigate polymorphisms cytochrome $2 \mathrm{~B} 6$ and concomitant rifampicin use on the plasma concentration of Efavirenz $600 \mathrm{mg}$ vs. $800 \mathrm{mg}$ on HIV-infected Ivoirians.

Methods: Consenting African patients with TB and HIV have received antiretroviral therapy including Efavirenz 600 and $800 \mathrm{mg}$, with rifampicin were observed. Efavirenz exposure was performed by HPLC MS-MS and Fluorimetric 5' nuclease genotyping Assay (Atman Assays. Applied Biosystems Foster City, CA, USA) was used to genetic determination.

Results: 19 randomized patients undergone genotyping, the median age was 34 years [30-41], 09 (47\%) of women, the median weight was $55 \mathrm{~kg}$, with extremes [49-62], the rate basic of CD4 were $173 / \mathrm{mm}^{3}$. The viral load was $6.10 \log 10$ in basic (5.66 - 6.42), the Akan ethnic group was essential in our sample with $10(52.65 \%), 04(21.1 \%)$ patients were alcoholics. GG (47.370\%), GT (31.58\%) and TT (21.05\%). Efavirenz $600 \mathrm{mg}$ plasma concentration and genetic polymorphism showed no significative difference (P-value > 0.05). Also Efavirenz 800 Plasma concentration and genetic polymorphism showed no significative difference (P-value $>0.05)$. Therapeutic Drugs monitoring of

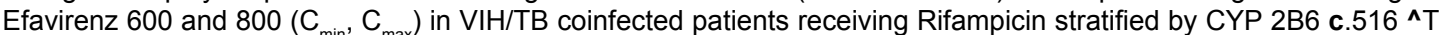
genotype during the time Week 4, Week 12, Week 24 by inter-series comparison don't show any significant difference $P$ value Kruskal Wallis $>0.05$.

Conclusion: Our study showed that the polymorphism does not alter significantly the values of concentrations, even if they remain well above the normal value on Caucasian patients. Others studies should be conducted to better assess the real impact of polymorphism on the plasma concentrations of Efavirenz in black.

\section{Introduction}

Efavirenz (EFV) is a non-nucleoside reverse transcriptase inhibitor (NNRTI) commonly prescribed in the first line antiretroviral regimen for the treatment of HIV/AIDS. EFV containing highly active antiretroviral therapy (HAART) is also preferred in patients with tuberculosis co-infection requiring rifampicin containing therapy [1]. Tuberculosis (TB) is the most common opportunistic infections in human immunodeficiency virus (HIV) infected patients, accounting for more than $50 \%$ in Cote d'Ivoire, and up to $60 \%$ of them die during treatment [2]. The mortality is reduced in HIV-TB co-infected patients who have started the combination antiretroviral therapy after diagnosis of TB [3]. Concomitant administration of highly active antiretroviral therapy (HAART) and anti-TB medications is often complicated due to drug-drug interactions with anti-tuberculosis antibiotics and the adverse effect profile of these co-administered drugs. As EFV is a potent and effective (NNRTI), it is the preferable option for initial antiretroviral treatments (ART) in HIV/TB co-infection. Rifampicin (RIF) is a critical component of TB therapy while it is a potent inducer of cytochrome P450 (CYP) enzyme activity [4,5]. The available pharmacokinetic data showed that rifampicin reduced of 13$25 \%$ the EFV plasma concentrations [4-6]. Recently, EFV was shown in vitro to be primarily metabolized by hepatic CYP2B6, with minor contributions from CYP3A4 and CYP2A6 [6-8]. While RIF is an inducer of CYP3A4, CYP2B6 and CYP3A4 genotypes are evidenced to be associated with altered activity of hepatic enzymes in the liver and EFV pharmacokinetics that may influence efficacy of treatment, since RIF's usually induces a decrease in EFV exposure [9-11]

The effect of CYP2B6 G516T on the EFV plasma exposure in African patient co- infected with HIV/TB taking rifampicin in the treatment TB as well as the implications of CYP2B6 genetic variation has not been investigated before in Africa especially in Ivoirian people (Cote d'Ivoire). We report an observational study describing the prevalence of CYP2B6 516 G.T, the concentration of EFV, in a cohort of West Africa patients with human immunodeficiency virus (HIV) infection.

*Corresponding author: Ayoman Thierry-Lenoir Djadji, Assistant Professor Department of Pharmacology, Felix Houphouet Boigny University, France, Tel: +225 07-79-7; E-djadji_thierry@yahoo.fr

Received: July 16, 2015; Accepted: August 10, 2015; Published: August 17, 2015

Citation: Djadji AT, Aba YT, Kassi NAC, Davolio A, Garraffo R, et al.(2015) Relationship between Efavirenz plasma concentrations and CYP2B6 Polymorphism in HIV/TB co-infected Africans taking rifampicin in the treatment Antituberculosis at Abidjan. Clin Exp Pharmacol 5: 185. doi:10.4172/2161-1459.1000185

Copyright: (c) 2015 Djadji AT. This is an open-access article distributed under the terms of the Creative Commons Attribution License, which permits unrestricted use, distribution, and reproduction in any medium, provided the original author and source are credited. 
Citation: Djadji AT, Aba YT, Kassi NAC, Davolio A, Garraffo R, et al.(2015) Relationship between Efavirenz plasma concentrations and CYP2B6 Polymorphism in HIV/TB co-infected Africans taking rifampicin in the treatment Antituberculosis at Abidjan. Clin Exp Pharmacol 5: 185. doi:10.4172/2161-1459.1000185

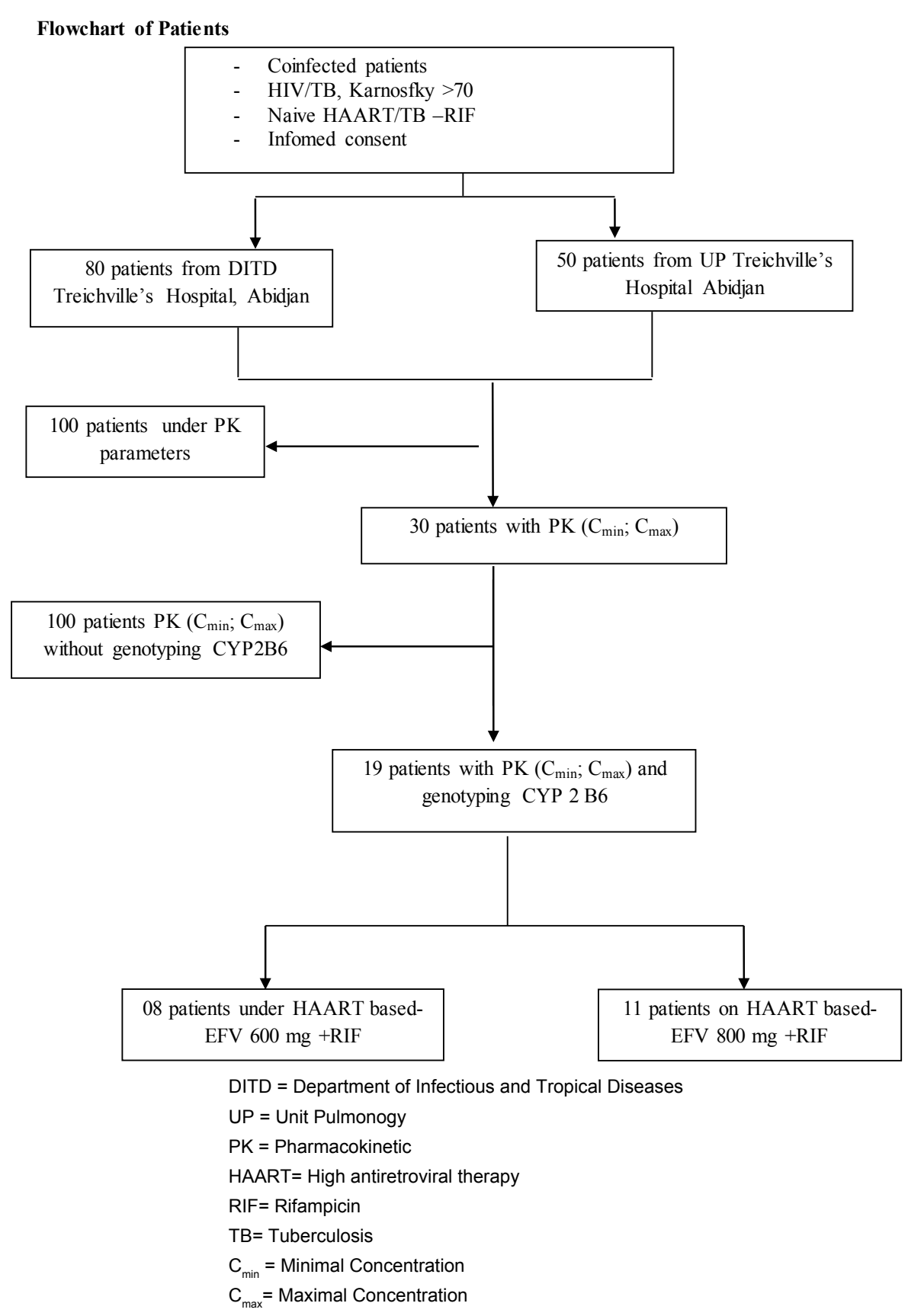

\section{Methods}

\section{Study design and patient population}

It was a randomized controlled trial for 130 patients from two centres: 80 patients of the Department of Infectious and Tropical Diseases and 50 patients in the pulmonology unit at Treichville's University hospital at Abidjan. The enrolment of patients was carried out from January 2007 to October 2008. Of the 130 patients only 19 have been genotyped for CYP450 polymorphism. Patients included in our study were HIV1/TB (pulmonary or extra-pulmonary) co-infected and presented rate of Karnowsky index $\geq 70 \%$, moreover, they were eligible, naive to antiretroviral and RIF treatment. They have given their consent by signing an informed consent agreement. This study was approved by the National Committee of Ethics. Tuberculosis (TB) was defined as clinical illness with tuberculosis accompanied by sputum smear positive for acid-fast bacilli or typical histopathological findings but also by lymphadenopathy in abdominal ultrasound. Eleven patients treated with Rifampicin (RIF)-based TB therapy received EFV $800 \mathrm{mg}$ and 8 patients with received EFV $600 \mathrm{mg}$. The antiretroviral treatments were (ZDV or D4T + 3TC + EFV600 + RHZE vs. ZDV or D4T+3TC + EFV800 + RHZE until 2 months and ZDV or D4T + 3TC + EFV60 $0+\mathrm{RH}$ vs. ZDV or D4T $+3 \mathrm{TC}+\mathrm{EFV} 800+\mathrm{RH}$ until 4 months). The main goal was to appreciate the influence of a CYP polymorphism on the level of the EFV minimal concentration $\left(\mathrm{C}_{\text {min }}\right)$ and maximal concentrations $\left(\mathrm{C}_{\max }\right)$ at 12 and 24 weeks. The pharmacokinetic parameters $\left(\mathrm{C}_{\max }, \mathrm{C}_{\min }\right)$ were determined at steady state for 30 patients in both arms of the study and only 19 patients have been the subject of our study (Table 1). The blood sample was collected in tubes 
Citation: Djadji AT, Aba YT, Kassi NAC, Davolio A, Garraffo R, et al.(2015) Relationship between Efavirenz plasma concentrations and CYP2B6 Polymorphism in HIV/TB co-infected Africans taking rifampicin in the treatment Antituberculosis at Abidjan. Clin Exp Pharmacol 5: 185. doi:10.4172/2161-1459.1000185

Page 3 of 4

\begin{tabular}{|c|c|c|c|c|c|c|c|c|c|c|c|c|}
\hline \multirow{2}{*}{\multicolumn{2}{|c|}{ Variables }} & \multirow[b]{2}{*}{ Total $(n=19)$} & \multirow[b]{2}{*}{ EFV600 $(n=8)$} & \multirow[b]{2}{*}{ EFV $800(n=11)$} & \multicolumn{3}{|l|}{ CYP2B6 } & \multicolumn{2}{|c|}{ CYP2B6 EFV600 } & \multicolumn{3}{|c|}{ CYP2B6 EFV800 } \\
\hline & & & & & $\begin{array}{l}\text { GG } \\
(n=9)\end{array}$ & $\begin{array}{l}\text { GT } \\
(n=6)\end{array}$ & $\begin{array}{l}\text { TT } \\
(n=4)\end{array}$ & $\begin{array}{l}\text { GG } \\
(n=3)\end{array}$ & $\begin{array}{l}\text { GT } \\
(n=5)\end{array}$ & $\begin{array}{l}\text { GG } \\
(n=5)\end{array}$ & $\begin{array}{l}\text { GT } \\
(n=1)\end{array}$ & $\begin{array}{l}\text { TT } \\
(n=4)\end{array}$ \\
\hline \multicolumn{2}{|c|}{ Age, years, median (IQR) } & $34(30-41)$ & $34(32.25-40)$ & $34(30-45)$ & $34(31-37)$ & $37,50(33-41)$ & $30(26.50-43)$ & & & $\begin{array}{l}35,50 \\
(30-39)\end{array}$ & $\begin{array}{l}45 \\
(45-45)\end{array}$ & $\begin{array}{l}30 \\
(26,50-43)\end{array}$ \\
\hline \multicolumn{2}{|c|}{ Sex, Female (\%) } & $09(47)$ & & $6(54.5)$ & $4(44.4)$ & $3(50)$ & $2(50)$ & $0(0)$ & $3(60)$ & $4(66.7)$ & $0(0)$ & $2(50)$ \\
\hline \multicolumn{2}{|c|}{ Weight, Kg, median (IQR) } & $55(49-62)$ & $\begin{array}{l}58(49,25- \\
62.75)\end{array}$ & $53(49-60)$ & & & & & & & & \\
\hline \multicolumn{2}{|c|}{$\begin{array}{l}\text { Baseline CD4/mm3, } \\
\text { median (IQR) }\end{array}$} & $173(14-586)$ & & & & & & & & & & \\
\hline \multicolumn{2}{|c|}{$\begin{array}{l}\text { Basic viral load } \log _{10} \\
\text { median (IQR) }\end{array}$} & $\begin{array}{l}6.10(5.66- \\
6.42)\end{array}$ & $\begin{array}{l}5.97(5.61- \\
6.44)\end{array}$ & $6,11(5.47-6.40)$ & & & & & & & & \\
\hline \multirow{3}{*}{$\begin{array}{l}\text { Group* ethnic } \\
(\%)\end{array}$} & Akan & $10(52.6)$ & $5(62.5)$ & $5(455)$ & $4(44.4)$ & $3(50)$ & $3(75)$ & $3(100)$ & $2(40)$ & $1(16.7)$ & $1(100)$ & $3(75)$ \\
\hline & Krou & $5(26.3)$ & $2(25.0)$ & $3(27.3)$ & $2(22.2)$ & $2(33.3)$ & $1(25)$ & $0(0)$ & $2(40)$ & $2(33.3)$ & $0(0)$ & $1(25)$ \\
\hline & Malinke & $4(21.1)$ & $1(12.5)$ & $3(27.3)$ & $3(33.3)$ & $1(16.7)$ & $0(0)$ & $0(0)$ & $1(20)$ & $3(50.0)$ & $0(0)$ & $0(0)$ \\
\hline \multicolumn{2}{|c|}{ Alcohol, yes, n (\%) } & $4(21.1)$ & $3(37.5)$ & $1(9.1)$ & $2(22.2)$ & $2(33.3)$ & $0(0)$ & $\begin{array}{l}1 \\
(33.3)\end{array}$ & $2(40)$ & $1(16.7)$ & $0(0)$ & $0(0)$ \\
\hline
\end{tabular}

Group* ethnic (Akan, from the south and the middle Krou, from west, Malinke from the north of Cote d'Ivoire)

Table 1: Baseline demographic, clinical, and laboratory characteristics of study participants.

\begin{tabular}{|c|c|}
\hline Genotype & Frequency \\
\hline GG (Wild Type) & $9(47.37 \%)$ \\
\hline GT (Heterozygoteous mutant) & $6(31.58 \%)$ \\
\hline TT (Homozygoteous mutant) & $4(21.05 \%)$ \\
\hline
\end{tabular}

\section{CYP $2 B 6$ genetic variations}

The observed genotype frequencies for CYP 2B6 are shown in Table 2.

Table 2: Frequency of CYP2B6516 in 19 enrolled patients HIV/TB in Cote d'Ivoire.

containing EDTA for single nucleotide polymorphism (SNP) analysis, and for the determination of viral load and CD4. Tubes containing lithium heparin were used to collect the blood after 12 hours of administration of EFV between the $6^{\text {th }}$ week and $12^{\text {th }}$ week of ARV treatment. The study was conducted with a subgroup of 30 patients (15 patients in each group). Both RIF and $\mathrm{EFV} \mathrm{C}_{\max }$ and $\mathrm{C}_{\min }$ were collected at the beginning of treatment, then at 12 and 24 weeks treatment (Table 2). The first day at 8 o'clock in the morning was performed administration of TB treatment followed by sampling at $11 \mathrm{AM}$ for the determination of RIF, then an oral dose of EFV $600 \mathrm{mg}$ at bedtime $21 \mathrm{~h}$. Next day at 8 o'clock in the morning, TB treatment was given followed by a blood sample at 9' o'clock for EFV Cmax determination and at 9'oclock was performed Efavirenz sampling for the determination of $\mathrm{C}_{\max }$, at 8: PM sampling for assay of EFV.

\section{Drugs determinations}

EFV plasma concentrations were analysed in the Laboratory of Clinical Pharmacology and Medical Toxicology at the Hospital Pasteur (Nice, France) by a validated liquid chromatography LC/MSMS) methods. A simple extraction technique is performed by protein precipitation with acetonitrile $1000 \mu \mathrm{L}$ after addition of $100 \mu \mathrm{L}$ of atazanavir and amprenavir-d5-d4 to $1000 \mathrm{ng} / \mathrm{ml}$ as internal standard. The mixture is vortexed and centrifuged. An aliquot of supernatant $(150 \mu \mathrm{L})$ was injected. LC-MSMS system consists of Agilent 3200 series mass spectrometer coupled with Applied Biosystems 3200. Perfusion column (POROS R1/20, $20 \mu \mathrm{m}, 2.1 \mathrm{~mm}$ X30 Applied Biosystems Darmstadt, Germany). The chromatographic separation was performed on analytical columns consist of Phenyl Hexyl (Phenomenex Luna $5 \mu \mathrm{m}$, phenyl hexyl, $2 \mathrm{~mm}$ X $50 \mathrm{mmm}$, Aschaffenburg, Germany). HPLC operational procedures are conducted in two stages, the first, $10 \mu \mathrm{L}$ of the deproteinized sample is injected into the system and transferred into the column or the POROS analytes are absorbed, while the compound potentially interfering with the matrix, are washed

and freed waste directly by the mobile phase consisting of $15 \mathrm{mM}$ ammonium acetate, $0.1 \%$ formic acid with a flow rate of $2.7 \mathrm{~mL} / \mathrm{min}$ [11]. Normal values of the plasma concentrations ranged 1 and $4 \mathrm{mg}$ / L. The patients were genotyped for CYP2B6 c. 516G > T (Q172H, rs745274) Fluorimetric using 5 'nuclease genotyping Assay (TaqMan Assays. Applied Biosystems Foster City, CA, USA [12].

Statistics analysis: Data analysis was performed using SPSS.20 software and differences were considered significant at $\mathrm{p} \leq 0.05$. Also Kruskal Wallis and Mann-Whitney test were used to compare groups.

\section{Discussion}

To our knowledge, this was the first study describing the pharmacokinetics exposure of EFV in Ivoirians population. Three genotypes at CYP2B6 location 516 were described and characterized. Useful clinical observations were made on the relationship between these genotypes and EFV plasma levels, i.e. drug exposure. It is clear that the GG, GT, and TT genotypes followed a similar pharmacokinetic pattern, but with very different plasma levels at each respective time point. The aim of the study was to describe a possible significant relationship between EFV exposure and CYP polymorphism in HIV/ TB co-infected patients. Several important observations arise from this study. Our results indicate that EFV-metabolizing enzymes are induced to a maximum extent during the first months of RIF's therapy. The current study shows that, with respect to enzyme induction, during HIV/TB cotreatment, EFV has not significant additive or synergistic effect over and above on-going RIF's therapy.

Several studies have demonstrated the influence of race on metabolism and plasma concentrations of Efavirenz. Burger et al. [10] showed that race was a predictor and causes a significant increase in the plasma concentration EFV in non-Caucasians patients [13,14]. The relationship between CYP2B6 genotype and the pharmacokinetics of Efavirenz has been described in several studies [15].

The test control on the pharmacogenetics of Efavirenz in 19 patients focused on two groups was more in less homogeneous with respect to polymorphism and socio-demographic parameters. The frequency of GG genotype (wild-type), genotype GT (heterozygous mutant), and the TT genotype (homozygous mutant), were respectively 47.37, 31.58, and $21.05 \%$ in our study population. Efavirenz is mainly metabolized by CYP2B6, and the CYP2B6 gene is highly polymorphic. Many previous studies have shown CYP2B6 SNP, particularly G516T, to be associated 
Citation: Djadji AT, Aba YT, Kassi NAC, Davolio A, Garraffo R, et al.(2015) Relationship between Efavirenz plasma concentrations and CYP2B6 Polymorphism in HIV/TB co-infected Africans taking rifampicin in the treatment Antituberculosis at Abidjan. Clin Exp Pharmacol 5: 185. doi:10.4172/2161-1459.1000185

Page 4 of 4

with higher plasma EFV concentrations and its toxicity, which could result in an early discontinuation of antiretroviral therapy [16-18]. These values are similar to the results of Uttayamakul et al. $(38.46 \%$, $47.69 \%, 13.85 \%$ ) [19]. The prevalence of genetic polymorphisms seems underestimated due to the sample size, but remained significantly elevated as described in most of the work among Africans [20].

EFV $600 \mathrm{mg}$ Plasma concentration and genetic polymorphism showed no significative difference ( $\mathrm{p}$-value $>0.05$ ) (Table 3) However, the average of EFV $600 \mathrm{mg}$ plasma concentration were all $<1 \mathrm{mg} / \mathrm{L}$. $0.89(0.59-1.46)$ at $\mathrm{M}_{0}$ regardless of the polymorphism (GG and GT) and despite taking RIF. This could be explained by that enzymeinducing effect of RIF is higher at the beginning of treatment. Also, at doses of $600 \mathrm{mg}$ EFV with RIF, the $\mathrm{C}_{\text {min }}$ are in the normal ranges. The study did by Ramachandran et al. conducted in South India [21] and another study did by Cohen et al. [22] in South Africa (with a mean weight of $66 \mathrm{~kg}$ among participants) both demonstrated that CYP2B6 but not rifampicin co-administration influenced significantly the pharmacokinetics of EFV. The study by Kwara et al. [23] found that patients receiving rifampicin had significantly higher mean Efavirenz concentrations in those with the CYP2B6 genotype. This study further showed that nearly all the HIV-infected Ugandans on Efavirenz experienced toxic levels indicating that dosage adjustments previously suggested for Africa may be required to reduce toxicity [24].

Also EFV 800 mg plasma concentration and genetic polymorphism showed no statistically significant difference $(\mathrm{p}$-value $>0.05)$ (Table 4$)$ (P- Mann Whitney). However, the average concentrations are normal at $12^{\text {th }}$ Week and $24^{\text {th }}$ Week $(4 \mathrm{mg} / \mathrm{L})$ with no evidence of major adverse effects. Ivorians better tolerate Efavirenz. This could be explained by fact that enzyme-inducing effect of rifampicin is higher at the beginning of treatment. By the other hand Kwara et al. study [23] found that patients receiving rifampicin had significantly higher mean Efavirenz concentrations in those wearing with the CYP2B6 516TT genotype.

Efavirenz 600 and $800 \mathrm{mg}\left(\mathrm{C}_{\min }, \mathrm{C}_{\max }\right)$ in HIV/TB co-infected patients receiving Rifampicin stratified by CYP 2B6 during the time $4^{\text {th }}$ Week, $12^{\text {th }}$ Week, $24^{\text {th }}$ Week by inter-series comparison (Table 5) don't show any significant difference p-value Kruskal Wallis $>0.05$. We observed the high level of concentration. It is a study in which the distribution of patients in the two arms knows not made in a way homogeneous view of the polymorphism could explain the lack of significance.

Also the comparison of minimal and maximum concentrations based on the polymorphism showed no significance difference in this group. (P-value 0.05 , Mann Whitney). This would probably not only due to the weakness of our sample but also on how to select our patients (subpopulation). Early studies reported a 26\% reduction in the plasma Efavirenz concentration when co-administered with rifampicin, and the possible mechanism is that rifampicin induces the activity of the main metabolic enzyme, CYP2B6, which results in enhanced Efavirenz

\begin{tabular}{|c|c|c|c|c|c|}
\hline & \multirow{2}{*}{ Parameters } & \multicolumn{3}{|c|}{ Median (IQR) } & \multirow{2}{*}{$\begin{array}{c}\text { P Mann Whitney } \\
\text { GG vs. GT }\end{array}$} \\
\hline & & Total $(n=8)$ & $G G(n=3)$ & $\mathrm{GT}(\mathrm{n}=5)$ & \\
\hline \multirow{2}{*}{$4^{\text {th }}$ Week } & $\mathrm{C}_{\text {max }}, \mathrm{mg} / \mathrm{L}$ & $1.59(1.12-2.52)$ & $2.57(1.28-3.05)$ & $1.49(1.07-1.69)$ & 0.250 \\
\hline & $\mathrm{C}_{\min }, \mathrm{mg} / \mathrm{L}$ & $0.89(0.59-1.46)$ & $0.98(0.75-2.27)$ & $0.81(0.54-0.99)$ & 0.571 \\
\hline \multirow{2}{*}{$12^{\text {th }}$ Week } & $\mathrm{C}_{\max }, \mathrm{mg} / \mathrm{L}$ & $2.45(1.79-7.77)$ & $2.59(2.32-9.38)$ & $1.82(1.78-2.94)$ & 0.571 \\
\hline & $\mathrm{C}_{\min }, \mathrm{mg} / \mathrm{L}$ & $1.69(1.42-5.61)$ & $2.07(1.40-6.79)$ & $1.68(1.50-1.70)$ & 0.786 \\
\hline \multirow{2}{*}{$24^{\text {th }}$ Week } & $\mathrm{C}_{\max }, \mathrm{mg} / \mathrm{L}$ & $2.08(1.54-4.92)$ & $2.41(1.59-5.75)$ & $2.04(1.52-2.12)$ & 0.571 \\
\hline & $\mathrm{C}_{\min }, \mathrm{mg} / \mathrm{L}$ & $1.82(1.14-4.30)$ & $2.57(1.28-3.05)$ & $1.79(1.14-1.95)$ & 0.786 \\
\hline
\end{tabular}

The difference was no significant ( $p$-value 0.05)

Table 3: Efavirenz plasma concentrations after $600 \mathrm{mg}$ and genetic polymorphism.

\begin{tabular}{|c|c|c|c|c|c|c|c|c|}
\hline & \multirow{2}{*}{ Parameters } & \multicolumn{4}{|c|}{ Median (IQR) } & \multicolumn{3}{|c|}{ P Mann Whitney } \\
\hline & & Total $(n=11)$ & $G G(n=6)$ & $\mathrm{GT}(\mathrm{n}=1)$ & $\mathrm{TT}(\mathrm{n}=4)$ & GG vs. GT & GG vs. TT & GT vs. TT \\
\hline \multirow{2}{*}{$4^{\text {th }}$ Week } & $\mathrm{C}_{\max }, \mathrm{mg} / \mathrm{L}$ & $2.32(1.96-3.37)$ & $2.82(2.11-3.58)$ & $2.78(2.78-2.78)$ & $2.14(1.66-2.84)$ & 1 & 0.476 & 0.800 \\
\hline & $\mathrm{C}_{\min }, \mathrm{mg} / \mathrm{L}$ & $1.80(1.14-2.49)$ & $2.22(1.14-2.49)$ & $1.80(1.80-1.80)$ & $1.35(1.13-2.01)$ & 0.857 & 0.762 & 0.800 \\
\hline \multirow{2}{*}{$12^{\text {th }}$ Week } & $\mathrm{C}_{\max }, \mathrm{mg} / \mathrm{L}$ & $7.16(3.41-12.10)$ & $8.32(5.40-15.70)$ & $3.41(3.41-3.41)$ & $8.58(4.79-11.35)$ & 0.571 & 0.914 & 0.800 \\
\hline & $\mathrm{C}_{\min }, \mathrm{mg} / \mathrm{L}$ & $5.91(2.15-11.80)$ & $8.60(3.46-14.70)$ & $2.12(2.12-2.12)$ & $7.77(3.62-10.90)$ & 0.286 & 0.610 & 0,800 \\
\hline \multirow[t]{2}{*}{$24^{\text {th }}$ week } & $\mathrm{C}_{\max }, \mathrm{mg} / \mathrm{L}$ & $5.58(2.21-11.10)$ & $6.38(2.06-16)$ & $2.21(2.21-2.21)$ & $6.80(3.83-10.25)$ & 0.857 & 1 & 0,400 \\
\hline & $\mathrm{C}_{\min }, \mathrm{mg} / \mathrm{L}$ & $4.18(1.77-9.57)$ & $4.22(1.89-0.86)$ & $1.93(1.93-1.93)$ & $3.86(2.83-9.65)$ & 0.657 & 0.763 & 0,800 \\
\hline
\end{tabular}

Table 4: Efavirenz plasma concentrations after $800 \mathrm{mg}$ dose and CYP 2B6.

\begin{tabular}{|c|c|c|c|c|c|c|c|}
\hline & \multirow{3}{*}{ Parameters } & \multicolumn{5}{|c|}{ Median (IQR) } & \multirow{3}{*}{$\begin{array}{c}\mathrm{P}(\text { Total }) \\
\text { Kruskal Wallis Test }\end{array}$} \\
\hline & & \multicolumn{2}{|c|}{ EFV 600} & \multicolumn{3}{|c|}{ EFV800 } & \\
\hline & & $G G(n=3)$ & GT $(n=5)$ & $G G(n=6)$ & GT $(n=1)$ & TT $(n=4)$ & \\
\hline \multirow{2}{*}{$4^{\text {th }}$ Week } & $\mathrm{C}_{\max }, \mathrm{mg} / \mathrm{L}$ & $2.57(1,28-3.05)$ & $1.49(1.07-1.69)$ & $2.82(2.11-3.58)$ & $2.78(2.78-2.78)$ & $2.14(1.66-2.84)$ & 0.341 \\
\hline & $\mathrm{C}_{\min }, \mathrm{mg} / \mathrm{L}$ & $0.98(0.75-2.27)$ & $0.81(0.58-0.99)$ & $2.22(1.14-2.49)$ & $1.80(1.80-1.80)$ & $1.35(1.13-2.01)$ & 0.185 \\
\hline \multirow{2}{*}{$12^{\text {th }}$ week } & $\mathrm{C}_{\max }, \mathrm{mg} / \mathrm{L}$ & $2.59(2.32-9.38)$ & $1.82(1.78-2.94)$ & $8.32(5.40-15.70)$ & $3.41(3.41-3.41)$ & $8.58(4.79-11.35)$ & 0.205 \\
\hline & $\mathrm{C}_{\min }, \mathrm{mg} / \mathrm{L}$ & $2.07(1.40-6.79)$ & $1.68(1.50-1.70)$ & $8.60(3.46-14.70)$ & $2.12(2.12-2.12)$ & $7.73(3.62-10.90)$ & 0.165 \\
\hline \multirow{2}{*}{$24^{\text {th }}$ week } & $\mathrm{C}_{\max }, \mathrm{mg} / \mathrm{L}$ & $2.41(1.59-5.75)$ & $2.04(1.52-2.12)$ & $6.38(2.06-16.00)$ & $2.21(2.21-2.21)$ & $6.80(3.83-10.25)$ & 0.347 \\
\hline & $\mathrm{C}_{\min }, \mathrm{mg} / \mathrm{L}$ & $1.85(1.15-5.08)$ & $1.79(1.14-1.95)$ & $4.86(1.63-13.00)$ & $1.77(1.77-1.77)$ & $6,44(3.34-9.14)$ & 0.463 \\
\hline
\end{tabular}

Table 5: Efavirenz 600 and $800 \mathrm{mg}\left(\mathrm{C}_{\min }, \mathrm{C}_{\max }\right)$ in HIV/TB coinfected patients receiving Rifampicin stratified by CYP $2 \mathrm{~B} 6$ during the time $4^{\text {th }}$ week, $12^{\text {th }}$ week, $24^{\text {th }}$ week. 
Citation: Djadji AT, Aba YT, Kassi NAC, Davolio A, Garraffo R, et al.(2015) Relationship between Efavirenz plasma concentrations and CYP2B6 Polymorphism in HIV/TB co-infected Africans taking rifampicin in the treatment Antituberculosis at Abidjan. Clin Exp Pharmacol 5: 185. doi:10.4172/2161-1459.1000185

clearance and reduced plasma levels $[25,26]$. As a result, the US Food and Drug Administration approved a revised Efavirenz package insert recommending Efavirenz be increased from a standard daily dose of $600 \mathrm{mg}$ to $800 \mathrm{mg}$ for patients taking concomitant rifampicin who weigh greater than $50 \mathrm{~kg}$, based on empirical data from the two drug-drug interaction trials $[27,28]$ and semi-mechanistic population pharmacokinetic modelling.

In contrast, more recent and larger studies in HIV-infected patients with TB indicated either that there was no significant impact of rifampicin on Efavirenz concentrations [29]; or that rifampicin co-administration increased Efavirenz concentrations. The study by Kwara et al. found that patients receiving rifampicin had significantly higher mean Efavirenz concentrations in those with the CYP2B6 [30]. The authors hypothesized that the paradoxical effect may be due to increased susceptibility of the CYP2B6 (172-histidine) variant allozyme (resulting from the 516GRT polymorphism) to inhibition by one [30].

Comparison of the two focus groups (EFV 600 vs. EFV800) showed that whatever the polymorphism minimal concentrations are all above $1 \mathrm{mg} / \mathrm{L}$. These values are well above the minimum effective concentration and be able to prevent the emergence of viral resistance, however, the minimal concentrations of Efavirenz 800 M6 GG (8.88 $\mathrm{mg} / \mathrm{L})$, and TT $(5.42 \mathrm{mg} / \mathrm{L}$ ) are above the normal range ( $>4 \mathrm{mg} / \mathrm{L})$, this is due to the importance of the inter-individual [11]. As the minimal concentration of Efavirenz 800 M6 wild type patients is higher than the values in the homozygous mutant. The highest concentrations of Efavirenz 800 M6 GG $(11.26 \mathrm{mg} / \mathrm{L})$ and TT $(6.52 \mathrm{mg} / \mathrm{L})$ are also well above normal values could therefore exposed patients to potential adverse effects. However it should be noted that, despite the high levels of peak plasma concentrations, there were no adverse effects in any patients.

The values of minimal concentrations of Efavirenz $600 \mathrm{mg}$ in spite of the combination of rifampicin and whatever the polymorphism are $>1 \mathrm{mg} / \mathrm{L}$. It seems sensible to prescribe dosages of EFV $600 \mathrm{mg}$ in African patients taking TB treatment rifampicin-based instead of EFV $800 \mathrm{mg}$. Polymorphism does not significantly influence the minimal concentrations or at least not as patients of the white races.

Our study reveals mostly through plasma concentrations higher among blacks $(>1 \mathrm{mg} / \mathrm{L})$ and the values of maximum plasma

\begin{tabular}{|c|c|c|c|c|c|c|c|c|c|c|}
\hline & \multirow{2}{*}{$\begin{array}{l}\text { Parameters } \\
\text { Median } \\
\text { (IQR) }\end{array}$} & \multicolumn{8}{|c|}{ Genotype CYP 2B6 (Total) } & \multirow{2}{*}{$\begin{array}{c}\mathrm{P} \\
\text { (Total) }\end{array}$} \\
\hline & & $\begin{array}{c}\text { GG (Akan) } \\
N=4\end{array}$ & $\begin{array}{c}\text { GG (Krou) } \\
N=2\end{array}$ & $\begin{array}{c}\mathrm{GG} \text { (Malinké) } \\
\mathrm{N}=3\end{array}$ & $\begin{array}{c}\text { GT(Akan)N } \\
N=3\end{array}$ & $\begin{array}{c}\text { GT (Krou) } \\
N=2\end{array}$ & $\begin{array}{c}\text { GT (Malinké) } \\
N=1\end{array}$ & $\begin{array}{c}\text { TT (Akan) } \\
\mathrm{N}=3\end{array}$ & $\begin{array}{c}\text { TT (Krou) } \\
\mathrm{N}=1\end{array}$ & \\
\hline \multirow{2}{*}{$\begin{array}{c}4^{\text {th }} \\
\text { week }\end{array}$} & $\mathrm{C}_{\max }, \mathrm{mg} / \mathrm{L}$ & $2.81(1.92-3.32)$ & $1.44(0.56-2.2)$ & $3,31(2.11-4.28)$ & $1.69(1.07-2.78)$ & $1.93(1.49-2.37)$ & $0.40(0.40-0.40)$ & $1,96(1.35-3.37)$ & $2.31(2.31-2.31)$ & 0.469 \\
\hline & $\mathrm{C}_{\min }, \mathrm{mg} / \mathrm{L}$ & $1.62(0.87-2.38)$ & $1.47(0.92-2.03)$ & $2.40(1.14-2.86)$ & $0.99(0.54-1.80)$ & $1.22(0.81-1.62)$ & $0.08(0.08-0.08)$ & $1.29(0.96-2.61)$ & $1.41(1.41-1.41)$ & 0.583 \\
\hline \multirow{2}{*}{$\begin{array}{c}12^{\text {th }} \\
\text { week }\end{array}$} & $\mathrm{C}_{\max }, \mathrm{mg} / \mathrm{L}$ & $2.81(1.92-3.32)$ & $1.44(0.56-2.32)$ & $3.31(2.11-4.28)$ & $1.69(1.07-2.78)$ & $1.93(1.49-2.37)$ & $0.40(0.40-0.40)$ & $1.96(1.35-3.37)$ & $2.31(2.31-2.31)$ & 0.347 \\
\hline & $\mathrm{C}_{\min }, \mathrm{mg} / \mathrm{L}$ & $1,62(0.87-2.38)$ & $1.47(0.92-2.03)$ & $2.40(1.14-2.86)$ & $0.99(0.54-1.80)$ & $1.22(0,81-1,62)$ & $0.08(0.08-0.08)$ & $1.29(0.96-2.61)$ & $1,41(1.41-1.41)$ & 0.213 \\
\hline \multirow{2}{*}{$\begin{array}{l}24^{\text {th }} \\
\text { week }\end{array}$} & $\mathrm{C}_{\max }, \mathrm{mg} / \mathrm{L}$ & $2.81(1.92-3.32)$ & $1.44(0.56-2.32)$ & $3.31(2.11-4.28)$ & $1.69(1.07-2.78)$ & $1.93(1.49-2.37)$ & $0.40(0.40-0.40)$ & $1.96(1.35-3.37)$ & $2.31(2.31-2.31)$ & 0.600 \\
\hline & $\mathrm{C}_{\min }, \mathrm{mg} / \mathrm{L}$ & $1.62(0.87-2.38)$ & $1.47(0.92-2.03)$ & $2.40(1.14-2.86)$ & $0.99(0.54-1.80)$ & $1.22(0.81-1.62)$ & $0.08(0.08-0.08)$ & $1.29(0.96-2.61)$ & $1.41(1.41-1.41)$ & 0.704 \\
\hline
\end{tabular}

Table 6: Ivoirians Ethnic groups; plasma concentration and CYP $2 \mathrm{~B} 6$.

\begin{tabular}{|c|c|c|c|c|c|c|c|}
\hline & & & & Timing $24^{\text {th }}$ week & & & \\
\hline \multirow[t]{4}{*}{ Treatment } & CYP2B6 & Timing W12 & $>4 \mathrm{mg} / \mathrm{L}$ & $<1 \mathrm{mg} / \mathrm{L}$ & $1-4 \mathrm{mg} / \mathrm{L}$ & Total row & P-value \\
\hline & & $>4 \mathrm{mg} / \mathrm{L}$ & 1 & & & $1(33)$ & \\
\hline & GG & $<1 \mathrm{mg} / \mathrm{L}$ & & & & & 0.333 \\
\hline & & $1-4 \mathrm{mg} / \mathrm{L}$ & & & 2 & $2(67)$ & \\
\hline \multirow[t]{10}{*}{ EFV 600} & & Total & 1 (33) & & $2(67)$ & 3 & \\
\hline & & $>4 \mathrm{mg} / \mathrm{L}$ & 1 & & & $1(20)$ & \\
\hline & GT & $<1 \mathrm{mg} / \mathrm{L}$ & & & & & 0.200 \\
\hline & & $1-4 \mathrm{mg} / \mathrm{L}$ & & & 4 & $4(80)$ & \\
\hline & & Total & $1(20)$ & & $4(80)$ & 5 & \\
\hline & & $>4 \mathrm{mg} / \mathrm{L}$ & & & & & \\
\hline & TT & $<1 \mathrm{mg} / \mathrm{L}$ & & & & & \\
\hline & & $1-4 \mathrm{mg} / \mathrm{L}$ & & & & & \\
\hline & & Total & & & & & \\
\hline & & $>4 \mathrm{mg} / \mathrm{L}$ & 3 & & 1 & $4(80)$ & \\
\hline \multirow[t]{11}{*}{ EFV 800} & GG & $<1 \mathrm{mg} / \mathrm{L}$ & & & & & 0.400 \\
\hline & & $1-4 \mathrm{mg} / \mathrm{L}$ & & & 1 & $1(20)$ & \\
\hline & & Total & $3(60)$ & & $2(40)$ & 5 & \\
\hline & & $>4 \mathrm{mg} / \mathrm{L}$ & & & & & \\
\hline & GT & $<1 \mathrm{mg} / \mathrm{L}$ & & & & & \\
\hline & & $1-4 \mathrm{mg} / \mathrm{L}$ & & & 1 & 1 & \\
\hline & & Total & & & 1 & 1 & \\
\hline & & $>4 \mathrm{mg} / \mathrm{L}$ & 3 & & 0 & $3(75)$ & \\
\hline & TT & $<1 \mathrm{mg} / \mathrm{L}$ & & & & & 0.250 \\
\hline & & $1-4 \mathrm{mg} / \mathrm{L}$ & & & 1 & $1(25)$ & \\
\hline & & Total & $3(75)$ & & $1(25)$ & 4 & \\
\hline
\end{tabular}

Table 7: Efavirenz plasma maximal concentration at $12^{\text {th }}, 24^{\text {th }}$ Week of EFV 600 and EFV 800. 
Citation: Djadji AT, Aba YT, Kassi NAC, Davolio A, Garraffo R, et al.(2015) Relationship between Efavirenz plasma concentrations and CYP2B6 Polymorphism in HIV/TB co-infected Africans taking rifampicin in the treatment Antituberculosis at Abidjan. Clin Exp Pharmacol 5: 185. doi:10.4172/2161-1459.1000185

Page 6 of 4

\begin{tabular}{|c|c|c|c|c|c|c|c|}
\hline \multirow[b]{2}{*}{ Treatment } & \multirow[b]{2}{*}{ Genotype 2 B6 } & \multirow[b]{2}{*}{$12^{\text {th }}$ Week } & \multicolumn{3}{|c|}{ Timing $24^{\text {th }}$ Week } & \multirow[b]{2}{*}{ Total row } & \multirow[b]{2}{*}{ P-value } \\
\hline & & & $>4 \mathrm{mg} / \mathrm{L}$ & $<1 \mathrm{mg} / \mathrm{L}$ & $1-4 \mathrm{mg} / \mathrm{L}$ & & \\
\hline & & $>4$ mg/L & 1 & & & $1(33)$ & \\
\hline & GG & $<1 \mathrm{mg} / \mathrm{L}$ & & & & & 0.333 \\
\hline & & $1-4 \mathrm{mg} / \mathrm{L}$ & & & 2 & $2(67)$ & \\
\hline \multirow[t]{10}{*}{ EFV 600} & & Total & $1(33)$ & & $2(67)$ & 3 & \\
\hline & & $>4$ mg/L & 1 & & & $1(20)$ & \\
\hline & GT & $<1 \mathrm{mg} / \mathrm{L}$ & & & 1 & $1(20)$ & 0.700 \\
\hline & & $1-4 \mathrm{mg} / \mathrm{L}$ & & 1 & 2 & $3(60)$ & \\
\hline & & Total & $1(20)$ & $1(20)$ & $3(60)$ & 5 & \\
\hline & & $>4$ mg/L & & & & & \\
\hline & TT & $<1 \mathrm{mg} / \mathrm{L}$ & & & & & \\
\hline & & $1-4 \mathrm{mg} / \mathrm{L}$ & & & & & \\
\hline & & Total & & & & & \\
\hline & & $>4$ mg/L & 4 & & 1 & $5(83)$ & \\
\hline \multirow[t]{11}{*}{ EFV 800} & GG & $<1 \mathrm{mg} / \mathrm{L}$ & & & & & 0.333 \\
\hline & & $1-4 \mathrm{mg} / \mathrm{L}$ & & & 1 & $1(17)$ & \\
\hline & & Total & $4(67)$ & & $2(33)$ & 6 & \\
\hline & & $>4$ mg/L & & & & & \\
\hline & GT & $<1 \mathrm{mg} / \mathrm{L}$ & & & & & \\
\hline & & $1-4 \mathrm{mg} / \mathrm{L}$ & & & 1 & $1(100)$ & \\
\hline & & Total & & & $1(100)$ & 1 & \\
\hline & & $>4$ mg/L & 3 & & & $3(75)$ & \\
\hline & TT & $<1 \mathrm{mg} / \mathrm{L}$ & & & & & 0.250 \\
\hline & & $1-4 \mathrm{mg} / \mathrm{L}$ & & & 1 & $1(25)$ & \\
\hline & & Total & $3(75)$ & & $1(25)$ & 4 & \\
\hline
\end{tabular}

Table 8: Efavirenz plasma minimal concentration at $12^{\text {th }}, 24^{\text {th }}$ Week of EFV 600 and EFV 800.

concentrations above $4 \mathrm{mg} / \mathrm{L}$ without causing major adverse effects appeared it would be interesting to evaluate or set values normal levels of maximum and minimum in the black subject, but also to make dose adjustments in patients receiving EFV and rifampicin taking into account the weight [30]. While enzyme induction of cytochrome P450 CYP2B6 rifampicin, co-administered to show an increase in the clearance of EFV and reduced plasma concentrations in Caucasians, it would set the blacks at the limits of plasma concentrations Efavirenz in, but by increasing the sampling to better assess the impact of the effect of cytochrome $\mathrm{P} 450$ on the plasma concentrations of co-administered with rifampicin Efavirenz among blacks.

Ethnic variations (Akans, Krou, and Malinké) did not show any significant difference regarding Efavirenz plasma concentrations whatever doses (Table 6). The Akans People come from Ghana and living in East, Middle, South of Côte d'Ivoire. The Krou come from Liberia and live west, Manlike come from the North. This study showed that regardless of the ethnicity of patients they would possess the same pharmacogenetic profiles $(\mathrm{P}>0.05)$.

The months of sampling, genotype, and RIF co-administration no influenced the percentages of patients in different EFV plasma concentration ranges. The percentage of patients with EFV plasma concentration $>4 \mathrm{mg} / \mathrm{L}$ was higher at Month 6 than a Month 3 of $\mathrm{EFV} \mathrm{C}_{\text {min }}$ by this association was not significant when tested using t-student test. $(\mathrm{P}>0.05)$ (Table 7). It was found that, about half of the patients under Efavirenz 800 had the values of plasma maximum concentrations $>4 \mathrm{mg} / \mathrm{L}$ regardless of the polymorphism at the first 3 months. This is especially true when well even minimal remains very high in some patients (Table 8 ). What justifies a reduction in dosage to 600 or $400 \mathrm{mg}$ of Efavirenz in combination therapy for TB because of possible adverse effects. Indeed, the study ENCORE1 findings suggest that a reduced dose of $400 \mathrm{mg}$ Efavirenz is non- inferior to the standard dose of $600 \mathrm{mg}$. Adverse events related to the study drug were more frequent with $600 \mathrm{mg}$ Efavirenz than with $400 \mathrm{mg}$. Lower dose Efavirenz should be recommended as part of routine care [31-33].

This study has a number of limitations. First, our population model was built from sparse sampling, and only 19 patients had extensive pharmacokinetic data available after week 24 .

\section{Conclusion}

Our study showed, despite the weakness of the sampling levels and high plasma trough concentrations demonstrating that the polymorphism does not significantly alter the values of concentrations, although they remain well above normal values of subject Caucasian. Other studies should be conducted to better assess the real impact of the polymorphism on efavirenz plasma concentrations in subjects black.

\section{Acknowledgment}

- $\quad$ Laboratory of Clinical Pharmacology and Medical de toxicology Hôpital Pasteur Nice France

- Laboratory of Clinical Pharmacology and Pharmacogenetics, Department of Infectious Diseases, University of Torino, Amedeo di Savoia Hospital, Corso Svizzera 164, 10149 Turin, Italy

Treichville Hospital

\section{References}

1. Panel on Antiretroviral Guidelines for Adults and Adolescents (2013) Guidelines for the use of antiretroviral agents in HIV-1-infected adults and adolescents. Department of Health and Human Services.

2. Maher DH, Getahun AH (2005) Tuberculosis and HIV interaction in SubSaharan Africa: Impact on patients and programmes; implications for policies. Med trop Int health 8: 734-742. 
Citation: Djadji AT, Aba YT, Kassi NAC, Davolio A, Garraffo R, et al.(2015) Relationship between Efavirenz plasma concentrations and CYP2B6 Polymorphism in HIV/TB co-infected Africans taking rifampicin in the treatment Antituberculosis at Abidjan. Clin Exp Pharmacol 5: 185. doi:10.4172/2161-1459.1000185

3. Manosuthi W, Thongyen S, Chaovavanich S, Sungkanuparph S, Chottanapand $S$ (2006) Survival rate and risk factors of mortality among HIV/ tuberculosis Co-infected patients with and without antiretroviral therapy. J Acquir Immune Defic Syndr 43: 42-46.

4. Benedek IH, Joshi A, Fiske WD (1998) Pharmacokinetic interaction between efavirenz and rifampin in healthy volunteers. Geneva, Switzerland.

5. Jindani A, Nunn AJ, Enarson DA (2004) Two 8-months regimens of chemotherapy for treatment of newly diagnostic pulmonary tuberculosis: International multi-center randomized trial. Lancet 364: 1244-1251.

6. Ramachandran G, Hemanth Kumar AK, Rajasekaran S, Kumar P, Ramesh $\mathrm{K}$, et al. (2009) CYP2B6 G516T polymorphism but not rifampin coadministration influences steady-state pharmacokinetics of efavirenz in human immunodeficiency virus-infected patients in South India. Antimicrob Agents Chemother 53: 863-868.

7. Nyakutira C, Roshammar D, Chigutsa E, Chonzi P, Ashton M, et al. (2008) High prevalence of the CYP2B6 516G-T(*6) variant and effect on the population pharmacokinetics of efavirenz in HIVIAIDS outpatients in Zimbabwe. Eur J Clin Pharmacol 64: 357-365.

8. Uttayamakul S, Likanonsakul S, Manosuthi W, Wichukchinda N, Kalambaheti T, et al. (2010) Effects of CYP2B6 G516T polymorphisms on plasma efavirenz and nevirapine levels when co-administered with rifampicin in HIV/TB coinfected Thai adults. AIDS Res Ther 7: 8.

9. Haas DW, Ribaudo HJ, Kim RB, Tierney C, Wilkinson GR, et al. (2004) Transcriptase inhibitor efavirenz: The effect of gender, race, Pharmacogenetics of efavirenz and central nervous system side effects: An Adult AIDS Clinical Trials Group study. AIDS 18: 2391-2400.

10. Marzolini C, Telenti A, Decosterd LA, Greub G, Biollaz J, et al. (2001) Efavirenz plasma levels can predict treatment failure and central nervous system side effects in HIV-1 infected patients. AIDS 15: 71-75.

11. Volosov A, Alexander C, Ting L, Soldin SJ (2002) Simple rapid method for quantification of anti-retrovirals by liquid chromatography-tandem massspectrometry. Clinical Biochemistry 35: 99-103.

12. Haas DW, Kwara A, Richardson DM, Baker P, Papageorgiou I, et al. (2014) Secondary metabolism pathway polymorphisms and plasma efavirenz concentrations in HIV-infected adults with CYP2B6 slow metabolizer genotypes. J Antimicrob Chemother. 69: 2175-2182.

13. Schale L, Moberg L, Svensson JO, Sonnerborg A (2004) Efavirenz plasma concentration in HIV infected patients: Inter intra-individual variability and clinical effects. Ther Drugs Monit 22: 267-270.

14. Ward BA, Gorski JC, Jones DR, Hall SD, Flockhart DA, et al. (2003) The cytochrome P450 2B6 (CYP2B6) is the main catalyst of Efavirenz primary and secondary metabolism: Implication for HIVIAIDS therapy and utility of efavirenz as a substrate marker of CYP2B6 catalytic activity. J Pharmacol Exp Ther 306: 287-300

15. Rotger M, Tequde H, Colombo S, Cavassini M, Furrer H, et al. (2007) Predictive value of known and novel alleles of CYP2B6 for efavirenz plasma concentrations in HIV-infected individuals. Clin Pharmacol Ther 81: 557-566.

16. Ingelman S M, Sim SC, Gomez A, Rodriguez A C (2007) Influence of cytochrome P450 polymorphisms on drug therapies: pharmacoge- netic, pharmacoepigenetic and clinical aspects. Pharmacol Ther 116: 496-526.

17. Wyen C, Hendra H, Siccardi M, Platten M, Jaeger H, et al. (2011) Cytochrome P450 2B6 (CYP2B6) and constitutive androstane receptor (CAR) polymorphisms are associated with early discontinuation of efavirenz-containing regimens. $J$ Antimicrob Chemother 66: 2092-2098.

18. Rotger M, Colombo S, Furrer H, Bleiber G, Buclin T, et al. (2005) Influence of CYP2B6 polymorphism on plasma and intracellular concentrations and toxicity of Efavirenz and nevirapine in HIV-infected patients. Pharmacogenet Genomics 15: 1-5.

19. Uttayamakul S, Likanonsaku S, Manosuthi W, Wichukchinda N, Kalambaheti $\mathrm{T}$, et al. (2010) Effects of CYP2B6 G516T polymorphisms on plasma efavirenz and nevirapine levels when co-administered with rifampicin in HIV/TB coinfected Thai adults. AIDS Res Ther 7: 8.

20. Ribaudo HJ, Hass DW, Tierney C, Kim RB, Wilkinson GR, et al. (2006) Pharmacogenetics of plasma Efavirenz exposure after treatment discontinuation An adult aids clinical trials group study. Clin Infect Dis 42: 401-407.
21. Ramachandran G, Kumar AKH, Rajasekaran S, Kumar P, Ramesh K, et al. (2009) CYP2B6 G516T Polymorphism but Not Rifampin Co-administration Influences Steady-State Pharmacokinetics of Efavirenz in Human Immunodeficiency Virus-Infected Patients in South India Antimicrob. Agents Chemother 53: 863-868.

22. Cohen K, Grant A, Dandara C, Mcllleron H, Pemba L, et al. (2009) Effect of rifampicin-based anti-tubercular therapy and the cytochrome P450 2B6 516G. $T$ polymorphism on efavirenz concentrations in adults in South Africa. Antivir Ther 14: 687-695.

23. Kwara A, Lartey M, Sagoe KW, Xexemeku F, Kenu E, et al. (2008) Pharmacokinetics of efavirenz when co-administered with rifampin in TB/ HIV co-infected patients: Pharmacogenetic effect of CYP2B6 variation. J Clin Pharmacol 48: 1032-1040.

24. SR Penzak, G Kabuye, P Mugyenyi, F Mbamanya, V Natarajan, et al. (2007) Cytochrome P450 2B6 (CYP2B6) G516T influences nevirapine plasma concentrations in HIV-infected patients in Uganda 8: 86-91

25. 25. Haas DW, Smeaton LM, Shafer RW, Robbins GK, Morse GD, et al. (2005) Pharmacogenetics of long-term responses to antiretroviral regimens containing Efavirenz and/or Nelfinavir: An Adult Aids Clinical Trials Group Study. J Infect Dis 192: 1931-1942.

26. Kwara A, Lartey M, Sagoe KW, Xexemeku F, Kenu E, et al. (2008) Pharmacokinetics of efavirenz when co-administered with rifampin in TB/ HIVco-infected patients: Pharmacogenetic effect of CYP2B6 variation. J ClinPharmacol 48: 1032-1040.

27. Gatanaga H, Hayashida T, Tsuchiya K, Yoshino M, Kuwahara T, et al. (2007) Successful efavirenz dose reduction in HIV type 1-infected individuals with cytochrome P450 2B6 *6 and "26. Clin Infect Dis 45: 1230-1237.

28. Manosuthi W, Sungkanuparph S, Tantanathip P, Mankatitham W, Lueang niyomkul A, et al. (2009) Body weight cut-off for daily dosage of efavirenz and 60 -week efficacy of efavirenz-based regimen in human immunodeficiency virus and tuberculosis co-infected patients receiving rifampin. Antimicrob Agents Chemother 53: 4545-4548

29. Tsuchiya KG, Gatanaga H, Tackikawa N, Teruya K, Kikuschi Y, et al. (2004) Homozygous CYP2B6*6 (Q172H and K262R) correlates with high efavirenz concentrations in HIV-1 patients treated with standard efavirenz- containing regimens. Biochem Biophys Res commun 319: 1322-1326.

30. Leth FK, Kappelhoff BS, Johnson D, Losso MH, Boron-Kaczmarska A, et al. (2006) Pharmacokinetic parameters of nevirapine and efavirenz in relation to antiretroviral efficacy. AIDS Res Hum Retroviruses 22: 232-239.

31. Puls R, Amin J, Losso M, Phanuphak P, Nwizu C, et al. (2004) Efficacy of 400 $\mathrm{mg}$ efavirenz versus standard $600 \mathrm{mg}$ dose in HIV-infected, antiretroviral-naive adults (ENCORE1): A randomized, double-blind, placebo-controlled, noninferiority trial. The Lancet 383: $1474-1482$.

32. Gatanaga H, Hayashida T, Tsuchiya K, Yoshino M, Kuwahara T, et al. (2007) Successful efavirenz dose reduction in HIV type 1-infected individuals with cytochrome P450 2B6 *6 and "26. Clin Infect Dis 45: 1230-1237.

33. Manosuthi W, Sungkanuparph S, Tantanathip P, Mankatitham W, Lueang niyomkul A, et al. (2009) Body weight cut-off for daily dosage of efavirenz and 60 -week efficacy of efavirenz-based regimen in human immunodeficiency virus and tuberculosis co-infected patients receiving rifampin. Antimicrob Agents Chemother 53: 4545-4548. 